\title{
The Photomodulation Activity of Metformin Against Oral Microbiome
}

\author{
Shima Afrasiabi ${ }^{1}$, Maryam Pourhajibagher ${ }^{2}$, Abbas Bahador ${ }^{3 *}$ \\ ${ }^{1}$ Department of Microbiology, School of Medicine, Tehran University of Medical Sciences, Tehran, Iran \\ ${ }^{2}$ Dental Research Center, Dentistry Research Institute, Tehran University of Medical Sciences, Tehran, Iran \\ ${ }^{3}$ Oral Microbiology Laboratory, Department of Microbiology, School of Medicine, Tehran University of Medical Sciences, \\ Tehran, Iran
}

\section{*Correspondence to}

Abbas Bahador, Department of Microbiology, School of Medicine, Tehran University of Medical Sciences, Tehran, Iran.

Email: abahador@sina.tums.ac.ir

Published online July 6, 2019

\begin{abstract}
Periodontitis is one of the most common inflammatory diseases of the periodontium, which results in the inflammatory destruction of supporting structures around teeth and is closely associated with the development of systemic disease. Due to a wide variety of antibiotic resistance periodontopathic bacteria, photodynamic therapy (PDT) is a non-invasive adjunctive therapeutic modality that is capable of destroying the whole range of microbes. Metformin (Metf) is an antidiabetic drug, and recent studies suggest that cancer patients who receive Metf and are exposed to radiotherapy and chemotherapy show better outcomes. Our surveys in this review introduce Metf as a potent stimulus in increasing the efficacy of PDT in the induction of destruction in microbial cells.

Keywords: Antibiotic resistance; Metformin; Periodontitis; Periodontopathic bacteria; Photodynamic Therapy;
\end{abstract}

\section{Introduction}

In the last decade, the number of antibacterial drugs approved with a new mechanism of action has declined. ${ }^{1}$ The results of the misuse of these drugs are their adverse effects and particularly the expansion of bacterial resistance. $^{2}$ Resistance is often accompanied by the existence of antibiotic resistance genes which can be easily found in the oral microbiome. ${ }^{3}$ The importance of the commensal microbiota lies in its function as a reservoir of antibiotic-resistant microorganisms that some of them are also able to create local and systemic diseases. It has been shown that antibiotic resistance associated with periodontal microbiota has increased. ${ }^{4}$

Tooth loss and alveolar bone resorption in individuals with periodontal disease have occurred. ${ }^{5,6}$ In many countries, the incidence of periodontal disease has remained high, so that adults and young people are affected by severe periodontitis. ${ }^{7}$ Famous pathogens in producing periodontal diseases include Porphyromonas gingivalis and Fusobacterium nucleatum. ${ }^{8}$

Several studies show that some diseases are more strongly associated with the presence of periodontitis such as diabetes mellitus, ${ }^{9}$ rheumatoid arthritis, ${ }^{10}$ bacterial pneumonia, ${ }^{11}$ cardiovascular diseases, ${ }^{12}$ adverse pregnancy outcomes ${ }^{13}$ (premature birth, birth low birth weight, etc), and an increased risk of oral cancer. ${ }^{14}$ Oral squamous cell carcinoma (OSCC) is common cancer worldwide but occurs more frequently in individuals with oral bacteria. Compared with normal mucosa, OSCC surfaces have higher levels of periodontal pathogenic bacteria. ${ }^{15}$ In patients with untreated periodontal disease, they simplify the entry of bacteria and bacterial products into the bloodstream. ${ }^{16}$ Oral diseases such as dental caries and periodontal disease are directly associated with biofilm-related infections of the oral cavity. ${ }^{17} \mathrm{~A}$ biofilm is very resistant to antibiotics and human immunity. ${ }^{18}$ Oral biofilm antibiotic resistance can be transferred into or out of the oral cavity. ${ }^{19}$ the formation of the microbial biofilm is a common cause of morbidity and mortality in patients and leads to an increase in healthcare cost..$^{20}$

Photodynamic therapy (PDT) has the potential to become established as an antimicrobial approach, which appears best for localized infections under the conditions where antibiotics are not effective in the treatment of infection. ${ }^{21,22}$ Bacteria within the biofilms matrix are 2-1000 fold more resistant to an antimicrobial agent and PDT might be an optional therapeutic method to disrupt biofilms that cause oral disease via pathogenic bacteria. ${ }^{23,24}$ Metformin (Metf) increases apoptotic response ${ }^{25}$ and provides a synergistic advantage with chemotherapy

Please cite this article as follows: Afrasiabi S, Pourhajibagher M, Bahador A. The photomodulation activity of metformin against oral microbiome. J Lasers Med Sci. 2019;10(3):241-250. doi:10.15171/jlms.2019.39. 
and radiotherapy against certain cancers. ${ }^{26,27}$ This review focuses on the evaluation of the effect of the combined treatment of Metf and PDT on the treatment of periodontitis. In this review, data on PDT, Metf and the effect of their combination (PDT+Metf) against microorganisms, were collected from the published articles in PubMed, Google Scholar, and Scopus databases and prepared a review of the mentioned subjects.

\section{Photodynamic Therapy: Definition}

PDT contains the components of the visible light, photosensitizer (PS) and oxygen ${ }^{28}$ that form reactive oxygen species (ROS), causing the destruction of microorganisms. ${ }^{29}$

\section{Mechanism of Action of Photodynamic Therapy}

In the process of PDT, the components of the PS, when exposed to a particular light wavelength, gain a higher level of energy through the transition of electrons. In this exciting status, PS can react with oxygen and produce hydrogen peroxide $\left(\mathrm{H}_{2} \mathrm{O}_{2}\right)$, superoxide anion radical $\left(\mathrm{O}_{2}\right)$, and hydroxyl radicals $(\cdot \mathrm{OH})$ (process type $\mathrm{I}$ ) or react with oxygen to initiate the formation of reactive singlet oxygen $\left({ }^{1} \mathrm{O}_{2}\right)$ (process type II). ${ }^{30}$ The products produced in these reactions can cause considerable damage to the microorganisms or can change their metabolic activities irreversibly, thus resulting in death. ${ }^{31}$ When compared to other therapeutic methods, PDT has multiple benefits. PDT is a non-invasive and successful method in the treatment of the periodontal infection which results in killing a large variety of pathogens. ${ }^{32,33}$ The photo-activation allows better action for localized forms that decrease the complications of PDT, and can also be used to couple with other medical procedures. PDT is known as a cost-effective therapeutic approach due to the combination of low-cost PS and light sources. In addition, PDT has different cellular targets; thus, drug resistance does not happen. ${ }^{34}$

\section{Metf: Definition}

Metf (a biguanide drug) has commonly been used for decades for the treatment of diabetes type II. About 150 million people worldwide use Metf. It is derived from the plant Galega officinalis ${ }^{35}$ and has recently been suggested as an adjuvant treatment for cancer. ${ }^{36,37}$ Kim et al reported that radiation-sensitizing effect of Metf on hepatocellular carcinoma happened via increased apoptosis, cell cycle arrest, and enhanced DNA destruction. ${ }^{38}$

\section{Metformin: Mechanism of Action}

In eukaryotic cells, the primary target of Metf is complex-I of the electron transport chain leading to an accumulation of ROS and oxidative damage to lipids, protein, and DNA that could potentiate the effects of ionizing radiation. ${ }^{39,40}$ Complex-I (proton-pumping $\mathrm{NADH}$ ) is the first energy-transducing complex of many respiratory chains in eukaryotic cells and prepares the proton motive force required for energy consuming routes. In the respiratory chains of many bacteria, there is homologs of complex-I. ${ }^{41-43}$

In eukaryotic cells, the inhibition of complex-I by Metf results in decreased oxygen consumption and adenosine triphosphate (ATP) generation. Following the reduction in ATP production in eukaryotic cells, the cellular levels of adenosine monophosphate (AMP) increase and the energy sensor AMP-activated kinase $(\mathrm{AMPK})^{40}$ is activated. A serine/threonine protein kinase, known as AMPK, is comprised of a catalytic subunit $(\alpha)$ and two regulatory subunits $(\beta$ and $\gamma){ }^{44}$

When the amount of ATP concentrations is low, AMPK is activated and AMP concentrations enhance in response to food deprivation, hypoxia and Metf administration. ${ }^{45}$ AMPK activation improves the potency of neutrophils or macrophages to kill bacteria. Phagocytosis of bacteria as part of an innate immune response in the presence of macrophages and neutrophils plays a crucial role in the control of inflammation. ${ }^{46}$ In eukaryotic cells, various activators of AMPK have been shown to raise the phosphorylation of CLIP170 (CAP-Gly domaincontaining linker protein 1 ), which are required for microtubule dynamics. ${ }^{47,48}$

Inhibitions of AMPK and expression of a nonphosphorylate CLIP-170 mutant result in the improved accumulation of CLIP-170 at microtubule tips and slower tubulin polymerization. Additionally, AMPK inhibition results in microtubule instability. ${ }^{49}$ Pro-inflammatory responses and acute-phase proteins released during PDT can affect the immune system, which promote the penetration of a great number of inflammatory cells into the treatment site.

PDT immunological effects, when used for the treatment of local infections, make treatment more effective..$^{50,51}$ The results of studies have shown that 5-aminolevulinic acid (ALA)-mediated PDT effectively induces oxidative stress. ALA itself is not a PS and operates as the biological precursor in the heme biosynthetic pathway that can be biosynthesized in nearly all aerobic cells in mammals. Exogenous ALA administration leads to the accumulation of protoporphyrin IX in the mitochondria, which causes destruction to the mitochondria, reduces cellular ATP and causes impairment of mitochondrial function, following cell death after light irradiation. ${ }^{52-54}$ Furthermore, ALA has been shown to have considerable photo bactericidal activity and ALA could induce photodynamic inactivation effectively against various types of bacteria. ${ }^{52}$

\section{Nitric Oxide}

Nitrate is a component of human saliva that is converted to nitrite and nitric oxide (NO) rapidly by oral bacteria. ${ }^{55}$ $\mathrm{NO}$ is a ubiquitous, free radical gas, which plays a major role in various physiological and pathological processes $^{56}$ and may act as a potential biological marker 
for the detection of generalized chronic periodontitis. ${ }^{57}$ $\mathrm{NO}$ is produced via nitric oxide synthase (NOS) in the oral mucosa. The inducible type of NOS (iNOS) is one of the NOS isoforms, which is enhanced in the presence of periodontal disease. ${ }^{58,59}$ The intervention of NO in bone loss processes ${ }^{60}$ and the expression of iNOS in oral dysplasia and oral lichen planus have been reported. Also, DNA destruction caused by NO increases and may lead to the advance of oral cancer. ${ }^{58,61} \mathrm{NO}$ signals not only greater resistance to photokilling, but also a changed phenotype in surviving tumor cells which are characterized by more aggressive proliferation, migration, and invasion. ${ }^{62}$ In tumor cells, oxidative stress and leukocyte recruitment are NO-sensitive processes, which are induced by $\mathrm{PDT}^{63}$ and iNOS inhibitors in these cells can alleviate resistance to photokilling. ${ }^{64}$

Metf has inhibitory effects on the complex-I and therefore creates superoxide anion that reacts with $\mathrm{NO}$ to form reactive nitrogen species (RNS) such as peroxynitrite (ONOO-), which is a very potent inducer of DNA damage. ${ }^{65,66}$ Activation of AMPK is induced by $\mathrm{ONOO}^{67}$ and would inhibit iNOS by reducing the transcription of iNOS. $^{68}$

PDT induces the increase of superoxide dismutase activity. Excessive levels of superoxide during oxidative stress cause a reduction in $\mathrm{NO}$ by forming peroxynitrite. ${ }^{69,70}$

Metf, coupled with PDT, has a prooxidant role in the tumor cells and induces apoptosis in tumor tissue, compared to the administration of each one alone. NO levels reduce, thereby elevating nitrotyrosine formation. Nitrotyrosine is a stable indicator for RNS generation and confirms that they have a useful role in activating AMPK. ${ }^{25}$ In tumor models identified by moderately high production of NO, lowering the NO levels after PDT by NOS inhibitors (administered intravenously) appears to increase the rate of damage to treated tumors, as proposed by the improved tumor cure rates. ${ }^{71}$

\section{Apoptosis}

Apoptosis is a normal physiologic route, playing the main role in periodontitis. ${ }^{72,73}$ Disorders of apoptosis may contribute to a wide range of pathologies including oral diseases. ${ }^{74}$ Bacterial products produce pro-inflammatory factors. The inflammatory response has an important role in the expansion and progression of periodontitis. ${ }^{75}$

IL-4 is considered an anti-inflammatory cytokine that can modulate macrophage function and induce apoptosis in macrophages and monocytes. ${ }^{76}$ In patients with generalized aggressive periodontitis, the concentration of IL-4 is lower compared with healthy persons. ${ }^{77}$ Lack of IL-4 inhibits apoptotic cell death and may be responsible for the accumulation of macrophages in the inflammatory lesion and hence may contribute to the chronicity of the disease. ${ }^{78,79}$ Caspases, Tumor protein p53 (p53), and B-cell lymphoma 2 (Bcl-2) family members are chief factors in the apoptosis process (Figure 1). ${ }^{80-82}$

\section{P53 Tumor Suppressor}

The p53 tumor suppressor functions as a transcription factor which becomes activated by numerous stress stimuli. ${ }^{83}$ Some bacterial pathogens also actively prevent p53 protein and induce its degradation, resulting in variation of cellular stress responses. ${ }^{84}$ The infection of the gingival epithelial cell with $P$. gingivalis results in a decrease in p53 levels. By phosphorylation of kinases like Chk2, Aurora A, CK1delta and CK1epsilon, P53 is activated. All of these kinases are downregulated by $P$. gingivalis. ${ }^{85}$ A role for lipopolysaccharide (LPS) in the dysregulation of p53 has been confirmed. ${ }^{86}$ Dysregulation of immune pathways involved in periodontal disease causes chronic inflammation and tissue destruction. ${ }^{87}$ It has recently been reported that there is a relationship between P53 and increased immune response. ${ }^{88}$ Apoptosis can be induced via the expression of p53. ${ }^{89}$ PDT improves TP53 gene amplification. The major role of $\mathrm{p} 53$ in the PDT process

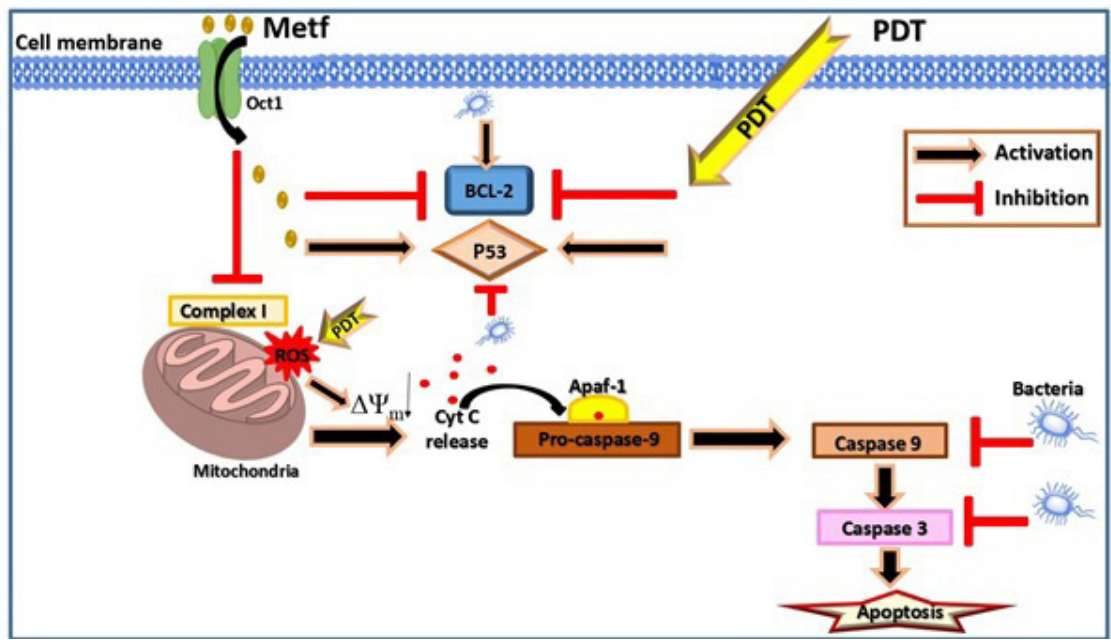

Figure 1. Interaction Between Metf, PDT and Microorganisms. 
has been shown for numerous clinically approved PSs. ${ }^{90,91}$ Metf induces radiosensitization in cancer cells lacking functional p53. ${ }^{92}$ Metf activates AMPK, which induces phosphorylation of p53 on serine $15 .{ }^{93,94}$ During cellular stress, phosphorylation at Ser-15 may be a serious event in the up-regulation and expression of $\mathrm{p} 53 .{ }^{95}$

Therefore, providing maximal therapeutic advantages in combination with PDT, Metf can increase the activity of P53 and thus microbial cells are more sensitive to PDT and increased apoptosis.

\section{BCL2 Family}

BCL2, as an anti-apoptotic protein, can inhibit cell death induced by a range of stimuli and prevents the release of cytochrome $c$ (Cyt $c$ ) from mitochondria. ${ }^{96}$ The higher incidence of BCL2 expression occurs in patients with chronic periodontitis and generalized aggressive periodontitis, as compared to the healthy gingival tissues. ${ }^{72,97}$ A significant tactic for $P$. gingivalis to survive in periodontal tissues is the ability to repress apoptosis. ${ }^{98}$ $P$. gingivalis can block apoptosis in gingival epithelial cells by the up-regulation of the BCL2. ${ }^{99}$ PDT degrades the BCL2 molecule, leading to apoptosis. ${ }^{100}$ BCL2 may undergo direct oxidative damage from PDT-generated ROS. ${ }^{101}$ BCL2 overexpression would protect cells from PDT-induced apoptosis and lead to impaired apoptosis after PDT. ${ }^{102}$ BCL2 forms a main factor of photokilling and shows that when PDT is joined with the suppressive factor of BCL2 function, synergistic effects can occur. ${ }^{103}$ In vivo, Metf decreases BCL2 expression, thereby inducing apoptosis. ${ }^{104}$ Therefore, the use of Metf in combination with PDT can increase apoptosis and the efficacy of PDT in the treatment of bacterial infections.

\section{Caspase Family}

Caspases (a cluster of intracellular cysteine proteases) are capable of cleaving substrates after aspartic acid residues and create certain morphological shifts related to apoptosis. ${ }^{105}$ Caspase- 3 is regarded as a more important player in apoptosis and cell death. ${ }^{106}$ Another important point in the induction of apoptosis is the stimulation of the apoptotic initiator caspase $9 .{ }^{107}$ During $P$. gingivalis infection, activation of both caspase- 9 and caspase- 3 are blocked strangely. ${ }^{15}$ Blocking the caspases results in a partial block in the loss of mitochondrial membrane potential $\left(\Delta \Psi_{\mathrm{m}}\right)$ and as a result, the diffusion of Cyt $c$ is stopped. ${ }^{108,109}$ The inhibition of caspase activation also blocks ROS production and promotes infection. ${ }^{110,111}$ Due to the production of ROS within mitochondria, loss of $\Delta \Psi_{\mathrm{m}}$ PDT causes mitochondrial damage. ${ }^{112}$

The prevention of complex-I and the generation of ROS induced by Metf should decrease the mitochondrial membrane potential ${ }^{113,114}$ and apoptosis by releasing Cyt $c$ from the mitochondrial inner membrane to the cytosol. ${ }^{115}$ Cyt $c$ by binding to proteins such as apoptotic protease activating factor 1 (Apaf 1) and procaspase 9 leads to the consecutive activation of caspase 9 and caspase 3, thus obligating the cell to apoptosis. ${ }^{116}$ It can be concluded PDT combined with Metf increases ROS production, result in structural damage in microbial cells . Therefore, use of PDT in combination of Metf may increase antimicrobial efficacy of PDT against local infections.

\section{Matrix Metalloproteinases Family}

Matrix metalloproteinases (MMPs) are members of a multigene family of zinc-containing enzymes that are capable of degrading all extracellular matrix (ECM) components. ${ }^{117,118}$

Deep periodontal pockets form due to the damage to ECM and alveolar bone loss. There are diverse pathways for the metabolic destruction of ECM. One pathway seems to be due to the activation of MMPs ${ }^{119}$ that may be involved in the degradation of collagen. ${ }^{120}$ Type I collagen is the most commonly lost part of the periodontium. ${ }^{121}$ MMP-2 has helicase activity that can cleave type I collagen. ${ }^{122}$ MMP-2 level is increased during inflammatory conditions such as periodontal disease. ${ }^{123}$ As we know, $P$. gingivalis is a key organism associated with the destruction of periodontal tissues. ${ }^{124} P$. gingivalis LPS can stimulate the production of prostaglandin (PG) E2 and promote the release of the MMP, which is associated with the development of gum disease. ${ }^{125}$

The enzyme cyclooxygenase-2 (COX-2) is responsible for the PGE2 production at sites of inflammation. ${ }^{126}$ COX-2 is induced by bacterial LPS; commensal bacteria might regulate constitutive COX-2 expression. ${ }^{127}$ Patients with periodontal disease have more COX-2 than healthy people. ${ }^{128}$

PDT induces MMPs, COX-2 expression, and release of PGE2, and the adjunctive use of MMP and COX2 inhibitor enhances PDT responsiveness. ${ }^{129-131}$ Metf has been reported to inhibit MMP-2 and COX-2 expression. ${ }^{132}$ The inhibition of MMP2 ameliorates mitochondrial damage, ${ }^{133}$ and the blockage of COX-2 expression increases the transcriptional activity of p53 and simplifies the decrease of $\Delta \Psi_{\mathrm{m}}$ induced by PDT. ${ }^{134}$

Metf plus PDT can diminish MMP-2 activity and COX2 expression in tumor tissues, compared to the patient who is treated with PDT. As a result of these effects, the combined use of inhibitors of COX-2 and MMP such as Metf as modulatory agents with aPDT with a reduction in $\Delta \Psi_{\mathrm{m}}$ enhances the release of Cyt $c$ and also increases the activity of P53. Moreover, it can induce apoptosis and prevent the tissue damage associated with periodontitis.

\section{NF-кB Signaling}

Nuclear factor kappa B (NF- $\kappa \mathrm{B})$ proteins are activated by microbial pathogens. ${ }^{135} \mathrm{NF}-\kappa \mathrm{B}$ has a fundamental role in the suppression of apoptosis induced by bacterial components like lipopolysaccharide. ${ }^{136}$ Lipopolysaccharide, hypoxia or decreased oxygen availability can induce NF- $\kappa \mathrm{B} \cdot{ }^{137,138} P$. gingivalis and 
F. nucleatum activate the NF- $\mathrm{B}$ pathway. ${ }^{139}$ Toll-Like Receptors (TLRs) are strong activators of the NF- $\mathrm{kB}$ intracellular pathway. ${ }^{140}$ Activation of TLRs on the cells of the periodontium leads to the overstated release of proinflammatory mediators, which may cause host tissue destruction. ${ }^{141}$ TLR4 expression is blocked by the NF- $\kappa B$ inhibitor. ${ }^{140}$ Neutralization of the NF- $\kappa B$ pathway might provide a useful therapeutic strategy in periodontitis. ${ }^{142}$ PDT reduces inflammatory markers NF-kB and inflammatory cytokines. ${ }^{143}$ Results show that TLR-4 level reduces significantly following PDT, which could have been due to damage/ inactivation of the LPS. ${ }^{144}$

Metf inhibits activation of NF-kB through the blockade of the phosphoinositide 3-kinase (PI3K)/Akt pathway. ${ }^{145,146}$ The PI3K-Akt signaling pathway is of considerable importance for survival and apoptosis. ${ }^{147}$ PI3K/Akt pathways are activated by TLR4 signaling via LPS. ${ }^{148}$ PI3K/Akt activity is required for NF-kB activity. ${ }^{149}$

\section{Conclusions}

The use of non-specific drug Metf in combination with PDT can be a solution for enhancing the effectiveness of PDT, leading to its potential role in the reduction of periodontal infections. This combination therapy induces oxidative stress, increases the rate of apoptosis, reduces levels of NO, and decreases expressions of MMP-2 and COX-2. Furthermore, it causes the inactivation of the NF- $\kappa B$ signaling pathway to occur. The experimental data for determining the dose of Metf and getting a better response during clinical trials are required. There has been little research in this area and this study could open a new approach in the treatment of bacterial infections.

\section{Ethical Considerations}

Not applicable.

\section{Conflict of Interests}

The authors declare no conflict of interest.

\section{References}

1. Maisch T. Antimicrobial photodynamic treatment-A helpful approach in immunocompromised patients. Photodiagnosis Photodyn Ther. 2011;8(2):178.

2. Zandbergen D, Slot DE, Niederman R, Van der Weijden FA. The concomitant administration of systemic amoxicillin and metronidazole compared to scaling and root planing alone in treating periodontitis: $=\mathrm{a}$ systematic review=. BMC Oral Health. 2016;16:27. doi:10.1186/s12903-015-0123-6

3. Sukumar S, Roberts AP, Martin FE, Adler CJ. Metagenomic insights into transferable antibiotic resistance in oral bacteria. J Dent Res. 2016;95(9):969976. doi:10.1177/0022034516648944

4. Soares GM, Figueiredo LC, Faveri M, Cortelli SC, Duarte PM, Feres M. Mechanisms of action of systemic antibiotics used in periodontal treatment and mechanisms of bacterial resistance to these drugs. J Appl
Oral Sci. 2012;20(3):295-309.

5. Hajishengallis G. Periodontitis: from microbial immune subversion to systemic inflammation. Nat Rev Immunol. 2015;15(1):30-44. doi:10.1038/nri3785

6. Kim J, Amar S. Periodontal disease and systemic conditions: a bidirectional relationship. Odontology. 2006;94(1):10-21. doi:10.1007/s10266-006-0060-6

7. Pleszczynska M, Wiater A, Bachanek T, Szczodrak J. Enzymes in therapy of biofilm-related oral diseases. Biotechnol Appl Biochem. 2017;64(3):337-346. doi:10.1002/bab.1490

8. Diaz PI, Zilm PS, Rogers AH. Fusobacterium nucleatum supports the growth of Porphyromonas gingivalis in oxygenated and carbon-dioxide-depleted environments. Microbiology. 2002;148(Pt 2):467-472. doi:10.1099/00221287-148-2-467

9. Preshaw PM, Alba AL, Herrera D, et al. Periodontitis and diabetes: a two-way relationship. Diabetologia. 2012;55(1):21-31. doi:10.1007/s00125-011-2342-y

10. Payne JB, Golub LM, Thiele GM, Mikuls TR. The Link Between Periodontitis and Rheumatoid Arthritis: A Periodontist's Perspective. Curr Oral Health Rep. 2015;2:20-29. doi:10.1007/s40496-014-0040-9

11. Bansal M, Khatri M, Taneja V. Potential role of periodontal infection in respiratory diseases - a review. $J$ Med Life. 2013;6(3):244-248.

12. Dhadse P, Gattani D, Mishra R. The link between periodontal disease and cardiovascular disease: How far we have come in last two decades ? J Indian Soc Periodontol. 2010;14(3):148-154. doi:10.4103/0972124x.75908

13. Srinivas SK, Parry S. Periodontal disease and pregnancy outcomes: time to move on? J Womens Health (Larchmt). 2012;21(2):121-125. doi:10.1089/jwh.2011.3023

14. Zuo C, Zhu Y, Wang X, Zeng X, Huang C. Tooth loss and risk of oral squamous cell carcinoma in Chinese Han population. Int J Clin Exp Med. 2015;8(11):2189321897.

15. Whitmore SE, Lamont RJ. Oral bacteria and cancer. PLoS pathogens. 2014;10(3):e1003933.

16. Jeffcoat MK, Jeffcoat RL, Gladowski PA, Bramson JB, Blum JJ. Impact of periodontal therapy on general health: evidence from insurance data for five systemic conditions. Am J Prev Med. 2014;47(2):166-174. doi:10.1016/j.amepre.2014.04.001

17. $\mathrm{Xu} \mathrm{P,} \mathrm{Gunsolley} \mathrm{J.} \mathrm{Application} \mathrm{of} \mathrm{metagenomics} \mathrm{in}$ understanding oral health and disease. Virulence. 2014;5(3):424-432. doi:10.4161/viru.28532

18. Høiby N, Bjarnsholt T, Givskov M, Molin S, Ciofu O. Antibiotic resistance of bacterial biofilms. International journal of antimicrobial agents. 2010;35(4):322-332.

19. Kim SM, Kim HC, Lee SW. Characterization of antibiotic resistance determinants in oral biofilms. J Microbiol. 2011;49(4):595-602. doi:10.1007/s12275-011-0519-1

20. Chen M, Yu Q, Sun H. Novel strategies for the prevention and treatment of biofilm related infections. International journal of molecular sciences. 2013;14(9):18488-18501.

21. Komerik N, MacRobert AJ. Photodynamic therapy as an alternative antimicrobial modality for oral infections. J Environ Pathol Toxicol Oncol. 2006;25(1-2).

22. Hamblin MR, Hasan T. Photodynamic therapy: a new 
antimicrobial approach to infectious disease? Photochem Photobiol Sci. 2004;3(5):436-450.

23. Chiniforush N, Pourhajibagher M, Parker S, Shahabi $\mathrm{S}$, Bahador A. The in vitro effect of antimicrobial photodynamic therapy with indocyanine green on Enterococcus faecalis: Influence of a washing vs nonwashing procedure. Photodiagnosis Photodyn The. 2016;16:119-123.

24. Beytollahi L, Pourhajibagher $M$, Chiniforush N, et al. The efficacy of photodynamic and photothermal therapy on biofilm formation of Streptococcus mutans: an in vitro study. Photodiagnosis Photodyn The. 2017;17:56-60.

25. Nenu I, Popescu T, Aldea MD, et al. Metformin associated with photodynamic therapy--a novel oncological direction. J Photochem Photobiol B. 2014;138:80-91. doi:10.1016/j.jphotobiol.2014.04.027

26. Libby G, Donnelly LA, Donnan PT, Alessi DR, Morris $A D$, Evans JM. New users of metformin are at low risk of incident cancer: a cohort study among people with type 2 diabetes. Diabetes Care. 2009;32(9):1620-1625. doi: $10.2337 / \mathrm{dc} 08-2175$

27. Giaccia AJ. Molecular radiobiology: the state of the art. J Clin Oncol. 2014;32(26):2871-2878. doi:10.1200/ jco.2014.57.2776

28. Robertson CA, Evans DH, Abrahamse H. Photodynamic therapy (PDT): a short review on cellular mechanisms and cancer research applications for PDT. J Photochem Photobiol B. 2009;96(1):1-8.

29. Huang Y-Y, Tanaka M, Vecchio D, et al. Photodynamic therapy induces an immune response against a bacterial pathogen. Expert Rev Clin Immunol. 2012;8(5):479-494.

30. Buytaert E, Dewaele M, Agostinis P. Molecular effectors of multiple cell death pathways initiated by photodynamic therapy. Biochim Biophys Acta. 2007;1776(1):86-107. doi:10.1016/j.bbcan.2007.07.001

31. Hamblin MR, O'Donnell DA, Murthy N, et al. Polycationic photosensitizer conjugates: effects of chain length and Gram classification on the photodynamic inactivation of bacteria. I Antimicrob Chemother. 2002;49(6):941-951.

32. Nitzan Y, Gutterman M, Malik Z, Ehrenberg B. Inactivation of gram-negative bacteria by photosensitized porphyrins. Photochem Photobiol. 1992;55(1):89-96.

33. Al-Zahrani MS, Bamshmous SO, Alhassani AA, AlSherbini MM. Short-term effects of photodynamic therapy on periodontal status and glycemic control of patients with diabetes. J Periodontol. 2009;80(10):15681573. doi:10.1902/jop.2009.090206

34. Bacellar IO, Tsubone TM, Pavani C, Baptista MS. Photodynamic Efficiency: From Molecular Photochemistry to Cell Death. Int $J$ Mol Sci. 2015;16(9):20523-20559. doi:10.3390/ijms160920523

35. Pryor R, Cabreiro F. Repurposing metformin: an old drug with new tricks in its binding pockets. Biochem J. 2015;471(3):307-322. doi:10.1042/bj20150497

36. Song CW, Lee H, Dings RP, et al. Metformin kills and radiosensitizes cancer cells and preferentially kills cancer stem cells. Sci Rep. 2012;2:362. doi:10.1038/ srep00362
37. Viollet B, Guigas B, Sanz Garcia N, Leclerc J, Foretz $\mathrm{M}$, Andreelli F. Cellular and molecular mechanisms of metformin: an overview. Clin Sci (Lond). 2012;122(6):253-270. doi:10.1042/cs20110386

38. Kim EH, Kim MS, Cho CK, Jung WG, Jeong YK, Jeong $\mathrm{JH}$. Low and high linear energy transfer radiation sensitization of HCC cells by metformin. J Radiat Res. 2014;55(3):432-442. doi:10.1093/jrr/rrt131

39. Haugrud AB, Zhuang Y, Coppock JD, Miskimins WK. Dichloroacetate enhances apoptotic cell death via oxidative damage and attenuates lactate production in metformin-treated breast cancer cells. Breast Cancer Res Treat. 2014;147(3):539-550. doi:10.1007/s10549-0143128-y

40. Koritzinsky M. Metformin: A Novel Biological Modifier of Tumor Response to Radiation Therapy. Int J Radiat Oncol Biol Phys. 2015;93(2):454-464. doi:10.1016/j. ijrobp.2015.06.003

41. Scheide D, Huber R, Friedrich T. The proton-pumping NADH:ubiquinone oxidoreductase (complex I) of Aquifex aeolicus. FEBS Lett. 2002;512(1-3):80-84.

42. Weiss H, Friedrich T, Hofhaus G, Preis D. The respiratory-chain NADH dehydrogenase (complex I) of mitochondria. EJB Reviews 1991: Springer; 1991:55-68.

43. Friedrich T, Scheide D. The respiratory complex I of bacteria, archaea and eukarya and its module common with membrane-bound multisubunit hydrogenases. FEBS Lett. 2000;479(1-2):1-5.

44. Salminen A, Kaarniranta K. AMP-activated protein kinase (AMPK) controls the aging process via an integrated signaling network. Ageing Res Rev. 2012;11(2):230-241. doi:10.1016/j.arr.2011.12.005

45. Hur KY, Lee MS. New mechanisms of metformin action: Focusing on mitochondria and the gut. J Diabetes Investig. 2015;6(6):600-609. doi:10.1111/jdi.12328

46. Bae HB, Zmijewski JW, Deshane JS, et al. AMPactivated protein kinase enhances the phagocytic ability of macrophages and neutrophils. Faseb J. 2011;25(12):4358-4368. doi:10.1096/fj.11-190587

47. Carling D, Thornton C, Woods A, Sanders MJ. AMPactivated protein kinase: new regulation, new roles? Biochem J. 2012;445(1):11-27.

48. Binker MG, Zhao DY, Pang SJ, Harrison RE. Cytoplasmic linker protein-170 enhances spreading and phagocytosis in activated macrophages by stabilizing microtubules. $J$ Immunol. 2007;179(6):3780-3791.

49. Nakano A, Kato H, Watanabe T, et al. AMPK controls the speed of microtubule polymerization and directional cell migration through CLIP-170 phosphorylation. Nat Cell Biol. 2010;12(6):583-590. doi:10.1038/ncb2060

50. Reginato E, Wolf $\mathrm{P}$, Hamblin MR. Immune response after photodynamic therapy increases anti-cancer and anti-bacterial effects. World J Immunol. 2014;4(1):1-11. doi:10.5411/wji.v4.i1.1

51. Reginato E, Mroz P, Chung H, Kawakubo M, Wolf P, Hamblin MR. Photodynamic therapy plus regulatory T-cell depletion produces immunity against a mouse tumour that expresses a self-antigen. $\mathrm{Br} J$ Cancer. 2013;109(8):2167-2174. doi:10.1038/bjc.2013.580

52. Hsieh CM, Huang YH, Chen CP, Hsieh BC, Tsai T. 5-Aminolevulinic acid induced photodynamic 
inactivation on Staphylococcus aureus and Pseudomonas aeruginosa. J Food Drug Anal. 2014;22(3):350-355. doi:10.1016/j.jfda.2013.09.051

53. Ji HT, Chien LT, Lin YH, Chien HF, Chen CT. 5-ALA mediated photodynamic therapy induces autophagic cell death via AMP-activated protein kinase. Mol Cancer. 2010;9:91. doi:10.1186/1476-4598-9-91

54. Tsai JC, Wu CL, Chien HF, Chen CT. Reorganization of cytoskeleton induced by 5 -aminolevulinic acidmediated photodynamic therapy and its correlation with mitochondrial dysfunction. Lasers Surg Med. 2005;36(5):398-408. doi:10.1002/lsm.20179

55. Takahama U, Hirota S, Takayuki O. Detection of nitric oxide and its derivatives in human mixed saliva and acidified saliva. Methods Enzymol. 2008;440:381-396. doi:10.1016/s0076-6879(07)00824-5

56. Choudhari SK, Chaudhary M, Bagde S, Gadbail AR, Joshi V. Nitric oxide and cancer: a review. World Journal of Surgical Oncology. 2013;11(1):118.

57. Reher VG, Zenobio EG, Costa FO, Reher P, Soares RV. Nitric oxide levels in saliva increase with severity of chronic periodontitis. J Oral Sci. 2007;49(4):271-276.

58. Ambe K, Watanabe H, Takahashi S, Nakagawa T, Sasaki J. Production and physiological role of NO in the oral cavity. Japanese Dental Science Review. 2016;52(1):1421.

59. Batista AC, Silva TA, Chun JH, Lara VS. Nitric oxide synthesis and severity of human periodontal disease. Oral Dis. 2002;8(5):254-260.

60. Leitao RF, Ribeiro RA, Chaves HV, Rocha FA, Lima V, Brito GA. Nitric oxide synthase inhibition prevents alveolar bone resorption in experimental periodontitis in rats. J Periodontol. 2005;76(6):956-963. doi:10.1902/ jop.2005.76.6.956

61. Brennan P, Thomas G, Langdon J. The role of nitric oxide in oral diseases. Arch of Oral Biol. 2003;48(2):93100.

62. Girotti AW. Modulation of the anti-tumor efficacy of photodynamic therapy by nitric oxide. Cancers (Basel). 2016;8(10). doi:10.3390/cancers8100096

63. Reeves KJ, Reed MW, Brown NJ. Is nitric oxide important in photodynamic therapy? J Photochem Photobiol B. 2009;95(3):141-147.

64. Girotti AW. Tumor-generated nitric oxide as an antagonist of photodynamic therapy. Photochem Photobiol Sci. 2015;14(8):1425-1432. doi:10.1039/ c4pp00470a

65. Zou M-H, Kirkpatrick SS, Davis BJ, et al. Activation of the AMP-activated protein kinase by the anti-diabetic drug metformin in vivo: role of mitochondrial reactive nitrogen species. J Biol Chem. 2004;279(42):4394043951.

66. Korkmaz A, Reiter RJ, Topal T, Manchester LC, Oter S, Tan DX. Melatonin: an established antioxidant worthy of use in clinical trials. Mol Med. 2009;15(1-2):43-50. doi:10.2119/molmed.2008.00117

67. Zou MH, Hou XY, Shi CM, et al. Activation of 5'-AMPactivated kinase is mediated through c-Src and phosphoinositide 3-kinase activity during hypoxiareoxygenation of bovine aortic endothelial cells. Role of peroxynitrite. J Biol Chem. 2003;278(36):34003-34010.
doi:10.1074/jbc.M300215200

68. Pilon G, Dallaire P, Marette A. Inhibition of inducible nitric oxide synthase by activators of AMP-activated protein kinase: a new mechanism of action of insulinsensitizing drugs. J Biol Chem. 2004;279(20):20767-74.

69. Chavez MD, Lakshmanan N, Kavdia M. Impact of superoxide dismutase on nitric oxide and peroxynitrite levels in the microcirculation--a computational model. Conf Proc IEEE Eng Med Biol Soc. 2007;2007:1022-1026. doi:10.1109/iembs.2007.4352468

70. Saczko J, Skrzypek W, Chwilkowska A, et al. Photooxidative action in cervix carcinoma cells induced by HPD - mediated photodynamic therapy. Exp Oncol. 2009;31(4):195-199.

71. Korbelik M, Parkins CS, Shibuya H, Cecic I, Stratford MR, Chaplin DJ. Nitric oxide production by tumour tissue: impact on the response to photodynamic therapy. Br J Cancer. 2000;82(11):1835-1843. doi:10.1054/ bjoc. 2000.1157

72. Bulut S, Uslu H, Ozdemir BH, Bulut OE. Expression of caspase-3, p53 and $\mathrm{Bcl}-2$ in generalized aggressive periodontitis. Head Face Med. 2006;2:17. doi:10.1186/1746-160x-2-17

73. Bantel H, Beikler T, Flemmig TF, Schulze-Osthoff K. Caspase activation is involved in chronic periodontitis. FEBS Let. 2005;579(25):5559-5564.

74. Misra A, Rai S, Misra D. Functional role of apoptosis in oral diseases: An update. J Oral Maxillofac Pathol. 2016;20(3):491-496. doi:10.4103/0973-029x.190953

75. Berker E, Kantarci A, Hasturk H, Van Dyke TE. Effect of neutrophil apoptosis on monocytic cytokine response to Porphyromonas gingivalis lipopolysaccharide. J Periodontol. 2005;76(6):964-971. doi:10.1902/ jop.2005.76.6.964

76. Atanasovska-Stojanovska A, Trajkov D, Nares S, Angelov N, Spiroski M. IL4 gene polymorphisms and their relation to periodontal disease in a Macedonian population. Hum Immunol. 2011;72(5):446-450. doi:10.1016/j.humimm.2011.02.005

77. Bastos MF, Lima JA, Vieira PM, Mestnik MJ, Faveri M, Duarte PM. TNF-alpha and IL-4 levels in generalized aggressiveperiodontitis subjects. OralDis. 2009;15(1):8287. doi:10.1111/j.1601-0825.2008.01491.x

78. Yamamoto M, Fujihashi K, Hiroi T, McGhee JR, Van Dyke TE, Kiyono H. Molecular and cellular mechanisms for periodontal diseases: role of Th1 and Th2 type cytokines in induction of mucosal inflammation. J Periodontal Res. 1997;32(1 Pt 2):115-119.

79. Sawa T, Nishimura F, Ohyama H, Takahashi K, Takashiba S, Murayama Y. In vitro induction of activation-induced cell death in lymphocytes from chronic periodontal lesions by exogenous Fas ligand. Infect Immun. 1999;67(3):1450-1454.

80. Elmore S. Apoptosis: a review of programmed cell death. Toxicol Pathol. 2007;35(4):495-516.

81. Zilfou JT, Lowe SW. Tumor suppressive functions of p53. Cold Spring Harbor perspectives in biology. 2009:a001883

82. Hardwick JM, Soane L. Multiple functions of BCL2 family proteins. Cold Spring Harb Perspect Biol. 2013;5(2):a008722. 
83. Jin S, Levine AJ. The p53 functional circuit. J Cell Sci. 2001;114(Pt 23):4139-4140.

84. Zaika AI, Wei J, Noto JM, Peek RM. Microbial regulation of p53 tumor suppressor. PLoS Pathogens. 2015;11(9):e1005099.

85. Kuboniwa $\mathrm{M}$, Hasegawa $\mathrm{Y}, \mathrm{Mao} \mathrm{S}$, et al. $\mathrm{P}$. gingivalis accelerates gingival epithelial cell progression through the cell cycle. Microbes Infect. 2008;10(2):122-128. doi:10.1016/j.micinf.2007.10.011

86. Tang X, Asano M, O’Reilly A, Farquhar A, Yang Y, Amar S. p53 is an important regulator of CCL2 gene expression. Curr Mol Med. 2012;12(8):929-943.

87. Cekici A, Kantarci A, Hasturk H, Van Dyke TE. Inflammatory and immune pathways in the pathogenesis of periodontal disease. Periodontology 2000. 2014;64(1):57-80.

88. Munoz-Fontela C, Mandinova A, Aaronson SA, Lee SW. Emerging roles of p53 and other tumour-suppressor genes in immune regulation. Nat Rev Immunol. 2016;16(12):741-750. doi:10.1038/nri.2016.99

89. Aoyama I, Yaegaki K, Calenic B, Ii H, Ishkitiev N, Imai T. The role of $\mathrm{p} 53$ in an apoptotic process caused by an oral malodorous compound in periodontal tissues: a review. $J$ Breath Res. 2012;6(1):017104. doi:10.1088/17527155/6/1/017104

90. Acedo P, Zawacka-Pankau J. p53 family members - important messengers in cell death signaling in photodynamic therapy of cancer? Photochem Photobiol Sci. 2015;14(8):1390-1396. doi:10.1039/c5pp00251f

91. Abo-Zeid MA, Liehr T, El-Daly SM, et al. Molecular cytogenetic evaluation of the efficacy of photodynamic therapy by indocyanine green in breast adenocarcinoma MCF-7 cells. Photodiagnosis Photodyn Ther. 2013;10(2):194-202. doi:10.1016/j.pdpdt.2012.11.006

92. Skinner HD, Sandulache VC, Ow TJ, et al. TP53 disruptive mutations lead to head and neck cancer treatment failure through inhibition of radiationinduced senescence. Clin Cancer Res. 2012;18(1):290300. doi:10.1158/1078-0432.ccr-11-2260

93. Sun Y, Tao C, Huang X, et al. Metformin induces apoptosis of human hepatocellular carcinoma HepG2 cells by activating an AMPK/p53/miR-23a/FOXA1 pathway. Onco Targets Ther. 2016;9:2845-2853. doi:10.2147/ott.s99770

94. Jones RG, Plas DR, Kubek S, et al. AMP-activated protein kinase induces a p53-dependent metabolic checkpoint. Mol Cell. 2005;18(3):283-293. doi:10.1016/j. molcel.2005.03.027

95. Tibbetts RS, Brumbaugh KM, Williams JM, et al. A role for ATR in the DNA damage-induced phosphorylation of p53. Genes Dev. 1999;13(2):152-157.

96. Srivastava $M$, Ahmad N, Gupta S, Mukhtar $H$. Involvement of Bcl-2 and Bax in photodynamic therapymediated apoptosis. Antisense $\mathrm{Bcl}-2$ oligonucleotide sensitizes RIF 1 cells to photodynamic therapy apoptosis. J Biol Chem. 2001;276(18):15481-15488. doi:10.1074/ jbc.M006920200

97. Kasprzak A, Hausmann M, Małkowska-Lanzafame A, et al. Immunocytochemical indicators of apoptosis in gingival tissues of patients with chronic periodontitis. Journal of Medical Science. 2016;83(1):37-46.
98. Nakhjiri SF, Park Y, Yilmaz O, et al. Inhibition of epithelial cell apoptosis by Porphyromonas gingivalis. FEMS Microbiol Lett. 2001;200(2):145-149. doi:10.1111/j.1574-6968.2001.tb10706.x

99. Stathopoulou PG, Galicia JC, Benakanakere MR, Garcia CA, Potempa J, Kinane DF. Porphyromonas gingivalis induce apoptosis in human gingival epithelial cells through a gingipain-dependent mechanism. BMC Microbiol. 2009;9:107. doi:10.1186/1471-2180-9-107

100. Koukourakis MI, Corti L, Skarlatos J, et al. Clinical and experimental evidence of Bcl-2 involvement in the response to photodynamic therapy. Anticancer Res. 2001;21(1b):663-668.

101. Chiaviello A, Postiglione I, Palumbo G. Targets and mechanisms of photodynamic therapy in lung cancer cells: a brief overview. Cancers (Basel). 2011;3(1):10141041. doi:10.3390/cancers3011014

102. Kim H-RC, Luo Y, Li G, Kessel D. Enhanced apoptotic response to photodynamic therapy after bcl-2 transfection. Cancer Res. 1999;59(14):3429-3432.

103. Kessel D. Promotion of PDT efficacy by a Bcl-2 antagonist. Photochem Photobiol. 2008;84(3):809-814. doi:10.1111/j.1751-1097.2007.00267.x

104. Feng Y, Ke C, Tang Q, et al. Metformin promotes autophagy and apoptosis in esophageal squamous cell carcinoma by downregulating Stat3 signaling. Cell Death Dis. 2014;5:e1088. doi:10.1038/cddis.2014.59

105. Jiang X, Wang X. Cytochrome c promotes caspase-9 activation by inducing nucleotide binding to Apaf-1. J Biol Chem. 2000;275(40):31199-31203.

106. Wall DM, McCormick BA. Bacterial secreted effectors and caspase-3 interactions. Cell Microbiol. 2014;16(12):1746-1756. doi:10.1111/cmi.12368

107. Renatus M, Stennicke HR, Scott FL, Liddington RC, Salvesen GS. Dimer formation drives the activation of the cell death protease caspase 9. Proc Natl Acad Sci U S A. 2001;98(25):14250-14255. doi:10.1073/ pnas. 231465798

108. Brentnall M, Rodriguez-Menocal L, De Guevara RL, Cepero E, Boise LH. Caspase-9, caspase- 3 and caspase-7 have distinct roles during intrinsic apoptosis. BMC Cell Biol. 2013;14:32. doi:10.1186/1471-2121-14-32

109. Chiu SM, Oleinick NL. Dissociation of mitochondrial depolarization from cytochrome $\mathrm{c}$ release during apoptosis induced by photodynamic therapy. Br J Cancer. 2001;84(8):1099-1106. doi:10.1054/bjoc.2000.1714

110. Ricci JE, Gottlieb RA, Green DR. Caspase-mediated loss of mitochondrial function and generation of reactive oxygen species during apoptosis. $J$ Cell Biol. 2003;160(1):65-75. doi:10.1083/jcb.200208089

111. Paiva CN, Bozza MT. Are reactive oxygen species always detrimental to pathogens? Antioxid Redox Signal. 2014;20(6):1000-1037.

112. Mroz P, Yaroslavsky A, Kharkwal GB, Hamblin MR. Cell death pathways in photodynamic therapy of cancer. Cancers. 2011;3(2):2516-2539.

113. Wheaton WW, Weinberg SE, Hamanaka RB, et al. Metformin inhibits mitochondrial complex I of cancer cells to reduce tumorigenesis. Elife. 2014;3:e02242. doi:10.7554/eLife.02242

114. Gao ZY, Liu Z, Bi MH, et al. Metformin induces apoptosis 
via a mitochondria-mediated pathway in human breast cancer cells in vitro. Exp Ther Med. 2016;11(5):17001706. doi:10.3892/etm.2016.3143

115. Wang $\mathrm{X}$. The expanding role of mitochondria in apoptosis. Genes Dev. 2001;15(22):2922-2933.

116. Li P, Nijhawan D, Budihardjo I, et al. Cytochrome c and dATP-dependent formation of Apaf-1/caspase- 9 complex initiates an apoptotic protease cascade. Cell. 1997;91(4):479-489.

117. Ferrario A, Chantrain CF, von Tiehl K, et al. The matrix metalloproteinase inhibitor prinomastat enhances photodynamic therapy responsiveness in a mouse tumor model. Cancer Res. 2004;64(7):2328-2332.

118. Lu P, Takai K, Weaver VM, Werb Z. Extracellular matrix degradation and remodeling in development and disease. Cold Spring Harb Perspect Biol. 2011;3(12):a005058. doi: 10.1101/cshperspect.a005058.

119. Bali P, Kalaivanan D, Divater V. Matrix metalloproteinases: A double edge sword. Dent Med Res. 2016;4(1):3-3.

120. Pittayapruek P, Meephansan J, Prapapan O, Komine M, Ohtsuki M. Role of Matrix Metalloproteinases in Photoaging and Photocarcinogenesis. Int J Mol Sci. 2016;17(6). doi:10.3390/ijms17060868

121. Honibald EN, Mathew S, Padmanaban J, Sundaram E, Ramamoorthy RD. Perioceutics: Matrix metalloproteinase inhibitors as an adjunctive therapy for inflammatory periodontal disease. J Pharm Bioallied Sci. 2012;4(Suppl 2):S417-421. doi:10.4103/09757406.100315

122. De Souza AP, Da Silva R, Da Silva M, CatanzaroGuimarães S, Line SRP. Matrix metalloproteinases: the most important pathway involved with periodontal destruction. 2005;4(15):884-890. doi:10.20396/bjos. v4i15.8641850

123. Franco C, Patricia HR, Timo S, Claudia B, Marcela H. Matrix metalloproteinases as regulators of periodontal inflammation. Int J Mol Sci. 2017;18(2). doi:10.3390/ ijms 18020440

124. How KY, Song KP, Chan KG. Porphyromonas gingivalis: An overview of periodontopathic pathogen below the gum line. Front Microbiol. 2016;7:53. doi:10.3389/ fmicb.2016.00053

125. Murakami Y, Machino M, Fujisawa S. Porphyromonas gingivalis fimbria-induced expression of inflammatory cytokines and cyclooxygenase- 2 in mouse macrophages and its inhibition by the bioactive compounds fibronectin and melatonin. ISRN Dent. 2012;2012:350859. doi:10.5402/2012/350859

126. Murakami Y, Yuhara K, Takada N, et al. Effect of melatonin on cyclooxygenase-2 expression and nuclear factor-kappa B activation in RAW264. 7 macrophagelike cells stimulated with fimbriae of Porphyromonas gingivalis. In Vivo. 2011;25(4):641-647.

127. Kirkby NS, Chan MV, Zaiss AK, et al. Systematic study of constitutive cyclooxygenase-2 expression: role of NF$\kappa \mathrm{B}$ and NFAT transcriptional pathways. Proceedings of the National Academy of Sciences. 2016;113(2):434-439.

128. Mesa F, Aguilar M, Galindo-Moreno P, Bravo M, O'valle F. Cyclooxygenase-2 expression in gingival biopsies from periodontal patients is correlated with connective tissue loss. J Periodontol. 2012;83(12):1538-1545.

129. Ferrario A, Chantrain CF, von Tiehl K, et al. The matrix metalloproteinase inhibitor prinomastat enhances photodynamic therapy responsiveness in a mouse tumor model. Cancer Res. 2004;64(7):2328-2332.

130. Sobolewski C, Cerella C, Dicato M, Ghibelli L, Diederich $\mathrm{M}$. The role of cyclooxygenase-2 in cell proliferation and cell death in human malignancies. Int J Cell Biol. 2010;2010.

131. Castano AP, Demidova TN, Hamblin MR. Mechanisms in photodynamic therapy: part two-cellular signaling, cell metabolism and modes of cell death. Photodiagnosis Photodyn Ther. 2005;2(1):1-23. doi:10.1016/s15721000(05)00030-x

132. Saber MM, Galal MA, Ain-Shoka AA, Shouman SA. Combination of metformin and 5-aminosalicylic acid cooperates to decrease proliferation and induce apoptosis in colorectal cancer cell lines. BMC Cancer. 2016;16:126. doi:10.1186/s12885-016-2157-9

133. Mohammad G, Kowluru RA. Novel role of mitochondrial matrix metalloproteinase-2 in the development of diabetic retinopathy. Invest Ophthalmol Vis Sci. 2011;52(6):3832-3841. doi:10.1167/iovs.10-6368

134. Song J, Wei Y, Chen Q, Xing D. Cyclooxygenase 2-mediated apoptotic and inflammatory responses in photodynamic therapy treated breast adenocarcinoma cells and xenografts. J Photochem Photobiol B. 2014;134:27-36. doi:10.1016/j.jphotobiol.2014.03.015

135. Hayden MS, Ghosh S. Shared principles in NF-kappaB signaling. Cell. 2008;132(3):344-362. doi:10.1016/j. cell.2008.01.020

136. Rahman MM, McFadden G. Modulation of NF-kappaB signalling by microbial pathogens. Nat Rev Microbiol. 2011;9(4):291-306. doi:10.1038/nrmicro2539

137. Harada K, Ohira S, Isse K, et al. Lipopolysaccharide activates nuclear factor-kappaB through toll-like receptors and related molecules in cultured biliary epithelial cells. Lab Invest. 2003;83(11):1657-1667.

138. D’Ignazio L, Rocha S. Hypoxia Induced NF-kappaB. Cells. 2016;5(1). doi:10.3390/cells5010010

139. Groeger S, Jarzina F, Domann E, Meyle J. Porphyromonas gingivalis activates NFkappaB and MAPK pathways in human oral epithelial cells. BMC Immunol. 2017;18(1):1. doi:10.1186/s12865-016-0185-5

140. Wan J, Shan Y, Fan Y, et al. NF-kappaB inhibition attenuates LPS-induced TLR4 activation in monocyte cells. Mol Med Rep. 2016;14(5):4505-4510. doi:10.3892/ mmr.2016.5825

141. Hans M, Hans VM. Toll-like receptors and their dual role in periodontitis: a review. J Oral Sci. 2011;53(3):263271.

142. Sahu K, Sharma M, Gupta PK. Modulation of inflammatory response of wounds by antimicrobial photodynamic therapy. Laser Ther. 2015;24(3):201-208. doi:10.5978/islsm.15-OR-13

143. Sharma M, Bansal H, Gupta PK. Virulence of Pseudomonas aeruginosa cells surviving photodynamic treatment with toluidine blue. Curr Microbiol. 2005;50(5):277-280. doi:10.1007/s00284-005-4473-1

144. Choi BH, Lee DH, Kim J, Kang JH, Park CS. Controls of Nuclear Factor-Kappa B Signaling Activity by 5'-AMP- 
Activated Protein Kinase Activation With Examples in Human Bladder Cancer Cells. Int Neurourol J. 2016;20(3):182-187. doi:10.5213/inj.1632718.359

145. Isoda K, Young JL, Zirlik A, et al. Metformin inhibits proinflammatory responses and nuclear factorkappaB in human vascular wall cells. Arterioscler Thromb Vasc Biol. 2006;26(3):611-617. doi:10.1161/01. atv.0000201938.78044.75

146. Martelli AM, Nyakern M, Tabellini G, et al. Phosphoinositide 3-kinase/Akt signaling pathway and its therapeutical implications for human acute myeloid leukemia. Leukemia. 2006;20(6):911-928. doi:10.1038/ sj.leu. 2404245

147. Saponaro C, Cianciulli A, Calvello R, Dragone T,
Iacobazzi F, Panaro MA. The PI3K/Akt pathway is required for LPS activation of microglial cells. Immunopharmacol Immunotoxicol. 2012;34(5):858-865. doi:10.3109/08923973.2012.665461

148. Bai D, Ueno L, Vogt PK. Akt-mediated regulation of NFkappaB and the essentialness of NFkappaB for the oncogenicity of PI3K and Akt. Int $J$ Cancer. 2009;125(12):2863-2870. doi:10.1002/ijc.24748

149. Milward MR, Chapple IL, Wright HJ, Millard JL, Matthews JB, Cooper PR. Differential activation of NF-kappaB and gene expression in oral epithelial cells by periodontal pathogens. Clin Exp Immunol. 2007;148(2):307-324. doi:10.1111/j.13652249.2007.03342.x 